\title{
8. The culture of impunity: What journalists need to know about international humanitarian law
}

\section{ABBSTRACI}

Whether they are nationals reporting wars occurring within their countries or international news media staff, journalists are facing growing dangers when covering conflict events. As civilians, they are protected to some extent by international humanitarian law (IHL). But what are these rules and how adequate is such coverage? The article details the core elements of IHL, its relevance for journalists and key issues of implementation and compliance. The news media profession has attempted in the last decade to strengthen normative protections which are discussed. The issue is viewed as one of continuing salience for the Pacific. The article concludes by observing that the issue of protection in combat for journalists is something that the profession has to confront systematically.

Keywords: conflict reporting, culture of impunity, hostage taking, international humanitarian law, legal protections, war crimes

\section{RODERIC ALLEY}

Victoria University of Wellington

ONCERNS about the welfare of journalists operating in settings of
conflict are justified and timely. The difficulties that they face are
usually substantial and often intimidating. Across a spectrum of risk
there is proximity to combat with threatened exposure to direct fire, mine
danger, improvised explosive devices, or stray bullets. Beyond immediate
physical danger comes the stress of working under conditions where the
security responsibility of any supposed 'authorities' is frequently arbitrary
and beyond the law. This culture of impunity leaves journalists in limbo
should they face targeted attack, 'disappearances', censorship, expulsion, 
harassment, summary arrest and detention, or trumped up charges delivered through suspect legal proceedings. The track record of bringing to justice those who have killed journalists in combat - a palpable war crime-has been lamentable.

Viewing the risks that journalists face when covering conflicts within states, commentator William Orme (2007) noted that the fear of being taken prisoner, real for journalists working in Iraq or Chechnya or the Afghan highlands is highly dangerous since potential captors may well lack knowledge of even the basics international humanitarian law. For him, being held hostage by guerrilla forces or a renegade pariah regime is a qualitatively different (and usually more frightening) experience than being an Axis or Allied prisoner of war in the 1940s.

Valuable equipment that journalists regularly carry risks theft for sale. Exposure to the rising criminality that accompanies worsening conflict is frequent. Worst of all, hostage taking and incarceration for either monetary ransom or broader political objectives are dangers that can never go discounted. As is often intended by their perpetrators, these actions seriously compromise the capacity of journalists to report fully and accurately, darkening the sunlight needed to nourish an informed global public. In the last two decades, threatening breakdowns of order on Bougainville and, to a lesser extent in the Solomon Islands, handicapped the reporting of these conflicts to wider Pacific audiences, one factor among others arguably prolonging them.

How else might we characterise these combat situations? Currently the international community is widely experiencing what are euphemistically termed 'complex humanitarian emergencies'. For one expert, this represents a 'conflict-related humanitarian disaster involving a high degree of breakdown of social dislocation and, reflecting this condition, requiring a system-wide response from the international community' (Duffield, 2001, p. 12). Such emergencies witness various stages of state failure, refugee flight, the spread of militias and warrior criminals, as well as populations at risk from disease, violence, predation and hunger.

Those conditions are not new, but a differentiation of their conflict intensity has accentuated, some locations (eg the Democratic Republic of the Congo (DRC)) worsening, but others (as in Bosnia) relatively quieter. Regardless of tempo, though, most conflicts remain internal to states. This is a salutary reminder that most journalists at risk are native to the surroundings 
concerned - as the November 2009 mass slaying of local media representatives in the Philippines all too tragically revealed. Indeed, the International Federation of Journalists has calculated that of the approximately 1200 journalists killed worldwide in the decade up to 2007,90 percent were local to the country in which they died. In the Pacific, journalists cannot ignore generally unsatisfactory implementation of humanitarian law, egregious violations evident during the 1990s Bougainville conflict.

What, then, of this article's central question: 'What should journalists know about the basics of the laws of war', a body of rules frequently referred to as international humanitarian law (IHL)? This subject was addressed by a 2007 meeting convened by the International Committee of the Red Cross (ICRC) and where the observations of Elaine Cobbe, an experienced television and radio reporter and media trainer deserve note. She asserted: 'I think it is important that journalists know the basics of international humanitarian law so that we in the media can point out what the laws of war say, even as some governments are "interpreting" them otherwise' (cited ICRC, 2007, p. 1).

Others conclude that an understanding about how to read events and situations from the angle of international humanitarian law makes war coverage more insightful and compelling. This would amplify how child soldiering (Uganda), concealed detention of combatants (Iraq), sexual violence by combatants against civilians (the DRC), or attacks on cultural or religious sites of no military value (Afghanistan) all constitute clear IHL violations. Assessment of these events is better informed through reference to standards and obligations specified under the soon discussed Geneva Conventions, now universally ratified although inadequately implemented. That law legitimises journalistic enquiry as to why it is not being upheld by any responsible authority, regardless of functional locus or political status. All states without exception are obligated to not only comply with these rules but - and this of close interest to journalists - also required to ensure respect for this body of law.

More broadly, violations of these laws often lie at the root of humanitarian and political crises, a useful lead for anyone writing a feature article investigating the reasons why a particular conflict has germinated into wider hostilities. Like sports reporters needing to know the rules of the games they cover so, too, do journalists covering situations of conflict.

At a wider public level, the humanitarian discourse is incomplete without hearing the civilian voices of those at the receiving end of physical conflict. 
These are stories that hold immediate interest to journalists, providing linkages of empathy that join readers to victims. Such connections have been broadened by the growth of human mobility and spread of international diasporas offering ready audiences for disaffected kith and kin, as well as the immediacy of instant electronic transmission conveying images of strife and suffering. This has been in evidence during recent conflicts including those in Gaza, Sri Lanka and Afghanistan. During the Bougainville conflict, humanitarian law violations by government and resistance forces alike energised and legitimised civil society formations that included the Leitana Nehan Women's Development Agency.

For all these reasons then, it is essential that journalists entering zones of conflict are familiar with the basics of IHL also referred to as the Law of Armed Conflict.

\section{International humanitarian law}

International humanitarian law in totality offers a set of rules that seek to limit the effects of armed conflict. In particular rules designed to protect those who are not combatants, or who have ceased being combatants. They do not answer the question of whether a particular war is lawful, this more a matter for the UN Charter. IHL is separate from, but can parallel and complement human rights law which involves protections within and against the state, as distinct from rules guiding conduct between states in situations of armed conflict. Both bodies of law, however, share a central philosophical and moral underpinning which is a principle of respect for the inherent dignity of every individual. That directly relates to the universality of IHL - a set of rules not just for soldiers or the protection of nurses and journalists, but for all humanity. Nobody, but nobody, is beyond the reach of this law. People here are either civilians or combatants, any attempt to insert hybrid categories soon encounter difficulties.

IHL sets limits on the means and methods employed in warfare. A variety of treaties and Conventions have been developed for this purpose ranging from the protection of property and cultural sites in conflict, to outright prohibitions on certain types of weaponry and means of conducting warfare. As well, there are general IHL principles and practices which states accept as binding because they follow existing state practice and are regarded as being in force. These are customary rules. Some are long standing and hallowed by 
precedent - including practices that recognise proportionality and limits to the use of force. In the Pacific, a research survey conducted under the auspices of the University of the South Pacific (Port Vila campus), found numerous instances where local cultures in conflicts of the past did observe rudimentary humanitarian law principles of restraint in the use of violence, codes of honour between combatants, and shame attached to the killing of women and children (Durham, 2008, 838-39). A fuller adumbration of these findings has been published by the International Committee of the Red Cross (Suva, 2009).

In recent years a major exercise has been conducted to collate customary IHL rules within one set of covers. This substantial task of codification and consolidation is now broadly completed although subject to updating. It is now available online (ICRC, 2010). When reviewing IHL in totality, we should keep some pivotal features constantly in view.

\section{Civilian protections}

A key principle concerns the civilian military distinction: IHL is designed to protect civilians as long as they are not making an effective contribution to military action. Here negative definitions apply: what is not military is civilian. What is military must - whether by location, function or purpose - make an effective contribution to military action. That is the constant. The variable factor is whether total or partial destruction, capture or neutralisation at the time of attack, offers a definite military advantage. That can prove difficult to calculate with accuracy, the greater the military advantage perceived, then the higher the risk of civilian casualties. Put basically as a bottom line however, it is unlawful to destroy objects that serve no military purpose whatsoever.

International humanitarian law protects those who do not take part in the fighting, such as civilians and medical and religious military personnel. It also protects those who have ceased to take part in hostilities, such as the wounded, the shipwrecked, those who are sick combatants, and prisoners of war (POWs). These rules are not nebulous and often convey specificity, for example at all times POWs must be protected, particularly against acts of violence or intimidation and against insults and public curiosity. Here the news media must remain mindful that, when showing or printing images of prisoners of war or of civilians, the dignity and security of prisoners of war or of civilians is not infringed. 
Specifically it is forbidden to kill or wound an enemy who surrenders or is unable to fight, while the sick and wounded must be collected and cared for by the party in whose power they find themselves. Medical personnel, supplies, hospitals and ambulances must all be protected. Anyone not formally coming under POW status - as in an internal war - is entitled to humanitarian treatment and due process. Critical here is constant monitoring, a function performed by the Red Cross. Visits to those incarcerated, conducted on a basis of impartiality and where confidence is critical for upholding this aspect of IHL. Regardless of their motives for doing so, the Taleban in Afghanistan since November 2009 are now facilitating such visits by Red Cross representatives.

What, then, of protections for journalists? As civilians they must not be directly attacked. Accredited war correspondents, while retaining civilian status, also gain formal POW status if captured (Third Geneva Convention). Note the word status - meaning that this extends beyond just treatment as a POW. Such POW status is endorsed by relevant identity card verification. If that is cast into doubt, then a determination by relevant tribunal is required. Whether that POW status would apply to accredited journalists in an internal war is more uncertain however, since they are not specifically mentioned in any treaty applicable to non-international armed conflicts. Nevertheless in such situations they are considered civilians being persons either not, or no longer taking a direct part in hostilities.

IHL does not protect the right of journalists to carry out their activities in zones of combat; there is nothing in these rules giving journalists greater access to war zones. What they do is address the humanitarian problems that journalists may face when engaged on these risky missions.

Fundamental guarantees apply to journalists when they are in the power of a party to any conflict-be that internal or international. The following acts are prohibited, at any time and in any place: violence to life, health, and physical or mental well-being, in particular murder, torture, and cruel or inhuman treatment; outrages upon personal dignity, in particular humiliating and degrading treatment; hostage-taking; and arbitrary deprivation of liberty.

By considering journalists as civilians, States agree to let them do their job, be that taking photographs, shooting films, recording information or taking notes with none of this constituting a reason for attack or deprivation of civilian protections. The rules of international humanitarian law thus offer an important safety net of protection to journalists and members of their crews. 
Journalists engaging in propaganda on behalf of a warring party also remain covered by these protections, but not to the extent that it materially contributes to so-called 'grave breaches' more fully explained later in this paper.

\section{Principles of proportionality and precaution}

Another key principle is proportionality in the means and methods of warfare, with the use of force not unlimited. Prohibitions exist against means and methods of warfare of a nature sufficient to cause superfluous injury or unnecessary suffering, or to cause long-term and severe damage to the natural environment. A reasonable balance must be struck between the effects of legitimate military destruction and undesirable collateral effects. What is plainly excessive is illegal-those planning and preparing military attacks must clearly be in a position to know and to decide what is excessive and what is not. Well trained and professional militaries do this - often a good deal more than is recognised.

Humanitarian law has banned the use of certain classes of weapons, including exploding dumdum bullets, chemical and biological weapons, blinding laser weapons and anti-personnel mines and, most recently, the 2008 Oslo Convention providing prohibitions on cluster munitions. Formulation of the 1997 Ottawa Convention prohibiting landmines, like that of the Oslo Convention on cluster munitions, saw active engagement by non-governmental organizations that have also played a central role in the ratification and implementation of these agreements. Active dissemination of humanitarian law is thus required for its effectiveness, the news media is a vital link in that process. Such coverage is uneven however; over the Ottawa Convention the New Zealand news media was more consistent than over the formulation of the Convention prohibiting cluster munitions. Here a critical conference held in Wellington in February 2008 received only cursory television news attention, despite being one of the biggest intergovernmental conferences ever held in the New Zealand capital. Pacific Islands delegations provided a positive contribution to these deliberations.

Further weapons prohibitions and protections to note include the:

- 1954 Convention for the Protection of Cultural Property in the Event of Armed Conflict, plus its two protocols;

- 1972 Biological Weapons Convention;

- 1983 Inhumane Weapons Convention (IWC) and the Convention on 
Certain Conventional Weapons (CCW) and its relevant Protocols.

- 1993 Chemical Weapons Convention;

- 2000 Optional Protocol to the Convention on the Rights of the Child on the involvement of children in armed conflict.

Missing in action from this list, however, remain effective international instruments curtailing the illicit transfer of small arms. For that objective to progress - something of immediate relevance to the Pacific - IHL principles and practices will require appropriate acknowledgment and incorporation into any future treaty. Another important principle is precautionary-where we see a blending of the previous principles of civilian protection and proportionality. This necessitates taking all feasible precautions in the choice of means and methods of attack so as to avoid or, at the very least, minimise incidental loss of civilian life, injury to civilians and damage to civilian objects. This means refraining from launching any kind of an attack expected to cause incidental loss of civilian life, injury to civilians or damage to civilian objects that is clearly excessive in relation to any concrete or direct military advantage being attempted. Here we must not neglect the responsibility of military commanders. Australian law, for example, makes commanders criminally responsible for IHL offences by forces under their command where there has been failure to exercise proper control. This would entail reckless failure to appreciate that forces under command are about to commit IHL offences, through failure to take all necessary and reasonable measures to prevent such actions, or negligence in subsequently submitting such a matter to competent authorities for investigation and prosecution.

Compliance failure here can incur international censure. In March 1997, the Secretary-General of Amnesty International, Pierre Sané, signed an open letter to Prime Minister Sir Julius Chan of Papua New Guinea. This claimed that, during the Bougainville conflict, many real and suspected members of the Bougainville Revolutionary Army had been unlawfully killed by the national Defence and Resistance forces in clear contravention of IHL. All forces, it urged, required IHL training (Amnesty International 1997). Since then, some IHL training of Papua New Guinea's Defence Forces has occurred, though impunity remains a problem, and among some local Police personnel.

When considering the key principles outlined, it is not difficult to detect a number of grey areas. Yet equally there is little difficulty in identifying what are clear-cut, palpable violations of these principles. Hence a deliberate 
attack causing the death or injury of a journalist is a war crime. By the same token it is incumbent on a professional journalist not to get so close to a target subject to an attack and considered likely to render a military advantage. Overall, the concept of protection is about the rights of people facing threats to their security and dignity, primarily as a result of conflict. More widely it encompasses activities aimed at obtaining full respect for human rights and refugee law. These functions are separate but complementary to IHL. They are rules that seek to strike a balance between humanitarian concerns and the military requirements of States.

\section{The Geneva Conventions of $\mathbf{1 9 4 9}$ and the Additional Protocols of 1977}

A major part of international humanitarian law is contained in the four Geneva Conventions of 1949. Every State in the world has agreed to be bound by them, though some have entered reservations as with the United States over the death penalty. The Conventions apply via individual instruments to civilians, the wounded, sick and shipwrecked, to prisoners of war, and to civilians including those under occupation. The Conventions have been developed and supplemented by two further agreements: the Additional Protocols of 1977 relating to a more comprehensive range of protections for victims of armed conflicts, and to non-international armed conflicts. A Third Protocol establishing a Third Emblem was agreed in 2005; it is gradually being ratified by states parties (51 as of December 2009) and is now increasingly in use.

Each of the four main Conventions specifies, if in slightly different wording, what are termed 'grave breaches' namely acts involving wilful killing, torture or inhuman treatment, including biological experiments, wilfully causing great suffering or serious injury to body or health, and extensive destruction and appropriation of property, not justified by military necessity and carried out unlawfully and wantonly. That conduct is criminalised. Conduct identified as a grave breach depends on the material scope of each particular Geneva Convention, for example the first dealing with the amelioration of the wounded and sick in armed forces in the field, or the Third Convention dealing deals with the treatment of Prisoners of War.

Any journalist dispensing material that is a clear incitement to grave breaches of Geneva Convention rules could become a legitimate military target - a possible example here being Radio Milles Collines and its deliberate 
dissemination of the ethnic hatred that fomented the 1994 Rwandan Genocide. (This tragedy recalls the sobering comment made by journalist Lindsey Hilsum covering that event, namely: 'Had I realised right at the start that I wasn't reporting anarchy but genocide, I would have reported it differently. In that first terrible week, I could have explained that governments have an obligation to stop it' (Cited in Pratt, 2005)).

Identifying who is a 'protected person' assumes importance here, namely those individuals coming under the coverage of each of the Geneva Conventions. Grave breaches may only be committed against protected persons within an international armed conflict. For non-international armed conflicts, we have seen a progressive expansion of rules, treaties and jurisdiction to criminalise violations. States carry the primary responsibility to prosecute this criminal conduct which thus decentralises this process.

Alternatively, individual crimes may be prosecuted by international or hybrid courts and tribunals. Under the 1998 Rome Statute establishing the International Criminal Court (ICC) the categorisation of war crimes under Article 8 of the ICC Statute, Section 2 refers to four categories of war crimes and embraces the Geneva Convention grave breaches provisions, violations of the next discussed Common Article 3, and what are termed other serious violations of the laws and customs applicable in both international and noninternational armed conflict.

\section{Common Article 3}

Common Article 3 to all four of the main Geneva Conventions is important because it deals with conflicts, now widespread, occurring within states and not of an international character. Common Article 3 elaborates minimum protections and standards of conduct to which the State and its armed opponents must adhere. The protections it spells out are at the core of international humanitarian law. Additional Protocol II of 1977 also covers internal armed conflicts, but it is less widely accepted among States than the 1949 Conventions.

Prohibitions include violence to life and person, in particular murder of all kinds, mutilation, cruel treatment and torture; taking of hostages; outrages upon personal dignity, in particular humiliating and degrading treatment; the passing of sentences and the carrying out of executions without previous judgment pronounced by a regularly constituted court, affording all the judicial guarantees recognised as indispensable by civilised peoples. 
IHL obliges States parties to suppress all of these violations. Certain of them are internationally criminalised as war crimes that include the violations listed as Grave breaches provisions in the Geneva Conventions and the Additional Protocols.

It is perhaps too easy to dismiss irregular, non-state militias and other localised combat formations as having no interest in either IHL rules or their implementation. However those formations with clear political agendas, not criminal intentions, may well want to gain and to hold public support. They know well that one of the quickest ways to lose support is to commit gross IHL violations. They will also propagandise to advantage against enemies who do. It is a fact that in Afghanistan the Taleban have recruited not just true believers to their cause, but those opposed to arbitrary use of force against them by government or coalition forces.

The criminalisation of IHL violations in non-international armed conflicts is gradually developing, the outcome of fuller recognition of customary rules as cited in a widely noted and debated ICTY Appeals Chamber ruling in the Tadić case of 1995 . This found that customary law imposes criminal liability for serious violations of Common Article 3, as supplemented by other general principles and rules for the victims of internal armed conflict, and for breaching certain fundamental principles and rules regarding the means and methods of combat in civil strife. Customary rules on the conduct of hostilities apply to all armed conflicts, international or non-international. Lagging behind, however, is the judicial infrastructure and international case law needed to make those rules watchwords of all relevant conduct.

\section{Towards enhanced implementation}

What about compliance? If the four Geneva Conventions of 1949, their two additional Protocols, and all relevant treaties mentioned comprise the hard drive, what about the necessary software needed to gets these rules immediately operative? Here we speak of necessary administrative regulatory and legislative provisions required to impart effectiveness. High on that list is the administration of justice and effective functioning of the rule of law. Without this domestic legal infrastructure the effective implementation of IHL is compromised - notwithstanding the development of international and hybrid tribunals. Where there is impunity or local failure to prosecute those responsible for egregious violations, IHL implementation is handicapped. 
States parties to the Geneva Conventions are required to respect and ensure respect for these rules and Conventions in all circumstances. This point needs emphasis. One party cannot evade its responsibilities on grounds that another entity is failing to uphold its obligations. States are bound by these Conventions even if an enemy has not acceded to them. And suspension clauses that might operate under other kinds of treaties have no place here.

States are required to pass the legislation that is needed to give full effect to these obligations including penal sanctions against those committing grave breaches. In particular, they must enact laws to punish those most serious violations of the Geneva Conventions and Additional Protocols regarded as war crimes. This has been facilitated by legislation passed in order to ratify the ICC Rome Statute. States must also pass laws protecting the Red Cross, Red Crescent and now Red Crystal emblems.

All too often IHL rules of protection are inadequately obeyed in practice, a key objective of relevant national dissemination committees being to enhance compliance. Lacking is a systematic means of agreed international enforcement, notwithstanding the existence of a seriously under-utilised International fact-finding commission able to investigate grave IHL breaches and other serious violations, and to offer good offices subject to state consent. Accordingly states bear the main responsibility for ensuring that these rules are widely known, fully obeyed, and effectively enforced meaning that violations are investigated and punished whenever and wherever they occur.

Sadly, there are countless examples of violation of international humanitarian law. Increasingly, the victims of war are civilians. But this is not going ignored. If we note 2009 conflicts in Gaza, Sri Lanka and Afghanistan, violations of IHL have been responded to by national Red Cross bodies and other interests committed to the upholding and promotion of IHL. These violations are not cost free for the international relations and global standing of those culpable.

Given that this body of law applies during times of extreme violence, fully implementing the law will always be a matter of great difficulty. That said, striving for effective compliance remains as urgent as ever. And there are important instances where international humanitarian law has made a substantial difference by protecting civilians, prisoners, the sick and the wounded, and in its restriction of the use of barbaric weapons.

Measures must be taken to ensure respect for international humanitarian 
law. States have an obligation to teach its rules to their armed forces and the general public. They must prevent violations or punish them if these should occur. Relevant here are the core, longstanding principles of humanitarian delivery exemplified by Red Cross and Red Crescent agencies, namely impartiality, neutrality and independence. Briefly, what do these entail?

Humanity refers to the basic social goal of alleviating human suffering by providing assistance and protection. Impartiality means that assistance and protection should be provided on the basis of need without discrimination on the basis of nationality, race, religion, political beliefs or on the basis of a possible outcome. Neutrality indicates a duty to refrain from taking part in hostilities, or from undertaking any action that furthers the interest of one party to a conflict. Independence maintains that humanitarian agencies not act as instruments of any government's foreign policy or be connected with any parties directly involved in an armed conflict. This can extend to a refusal to accept, or take a reduction of government funding should this principle risk compromise.

Agencies concerned would thus have problems with a 2001 statement made by former US Secretary of State Colin Powell when he claimed: 'I am serious about making sure we have the best relationship with the NGOs who are such a force multiplier for us, such an important part of our combat team ... it's a partnership... for those of us ... committed to the same, singular purpose to help ... every man and woman ... in need, who is hungry, who is without hope'.

The interface between what is civilian and what is military has become both more dense and complicated in many conflict arenas. Those mutual encroachments complicate the three key principles of impartiality, neutrality and independence just identified. The security dimension of humanitarian delivery has expanded considerably in the last two decades. Though under strain, these principles remain solid and enduring.

Yet none of what has been discussed need inhibit journalists subjecting IHL-related issues to searching and often salutary criticism. This includes inadequate uptake of the two 1977 Protocols, civilian violations such as rape that have worsened in the DRC, and evident shortcomings in global efforts to disseminate IHL. A mid-2009 eight country poll conducted by the ICRC saw an overwhelming majority (97 percent) endorsing the need to uphold clear distinctions between combatants and civilians in zones of conflict. However 
the same poll with its sample drawn from Afghanistan, the DRC, Liberia, Haiti, the Philippines, Lebanon, Georgia and Haiti, found that less than half (42 percent) had heard of the Geneva Conventions (ICRC, 2009)

\section{Specific journalist protections?}

The Third Geneva Convention characterised journalists as civilians attached to the military who, if captured, not be treated as spies, be not required to respond to interrogation and, if sick or wounded, remain entitled to prompt medical treatment. In the early 1970s attempts were made, some controversial, to have journalists designated a special battlefield status through particular insignia and identification — as do religious or medical staff. Those attempts did not succeed, being absorbed into the 1977 Additional Protocol formulation process. This was based on the claim that increasing the list of categories of those having special status risked diluting the value of each protective status already established.

Under Article 79 of Additional Protocol I of 1977, the civilian status of journalists was endorsed 'provided that they take no actions adversely affecting their status as civilians', the option made available of an identity card issued by that individual's government, territory of residence, or location of employing news medium, and attesting relevant professional status. We need to note however that the following states have not ratified Additional Protocol I: Burma, India, Indonesia, Iran, Iraq, Israel, Pakistan, Papua New Guinea, the Philippines, Somalia, Sri Lanka, Thailand, Turkey and the United States.

Since 1977 what of the claim that journalists in combat zones warrant special status protection on account of the public interest functions that they perform? In some of the subsequent jurisprudence (Prosecutor v. Radoslav Brdjanin and Monir Talic, 2002, ICTY Appeals Chamber) where it was recognised 'that public interest does not rest on a perception that of war correspondents occupying some special professional category. Rather, it exists because investigation and reporting by war correspondents enables citizens of the international community to receive vital information from war zones' (Balguy-Gallois, 2004, 4).

\section{Assisting journalists}

The Crimes of War Project is a collaboration of journalists, lawyers, and scholars dedicated to raising public awareness of the laws and their application in situations of conflict. This project's flagship publication, 
What the Public Should Know, which is regularly revised and available in a variety of languages, is widely utilised by journalists an A-Z guide covering the laws governing armed conflict and their application in practice; discussion of the crimes prohibited by international humanitarian law; key terms relating to modern warfare; analysis of legal categories; and case studies showing the place of war crimes in recent conflicts.

The ICRC maintains a Hotline service for media professionals who find themselves in trouble in armed conflicts, a service that deserves promotion among editors and the wider media community. This operates through a permanent contact point offering phone contact details that are readily available. If the ICRC is working in an area where a journalist is facing difficulties, it may be able to offer help, as it does to other civilians in similar situations. The services that the ICRC can provide are purely humanitarian.

IHL references to the protection of journalists (as in article 4 (4) of the Third Geneva Convention of 1949, and article 79 of the 1st Protocol of 1977) are somewhat sparse, but journalists need to know that states must at all times strictly adhere to their international obligations in regard to these provisions. That obligation was firmly endorsed by the unanimously adopted UN Security Council Resolution 1738 of December 2006. That resolution, inter alia, condemned intentional attacks on journalists, reaffirmed their civilian status with a call for full respect of their professional independence, demanded all parties to an armed conflict to fully comply with their IHL obligations, and called on all states to end impunity and prosecute those responsible for IHL violations. However, it 'is difficult to measure the efficacy of (this) resolution ... with no substantive accountability mechanism' (Lisosky \& Henrichsen, 2009, 144).

Although lacking legal edge, authoritative declarations and resolutions can shape protective norms treating the violations of journalists as grossly inappropriate. In 2003 Reporters without Borders formulated a Declaration on the safety of journalists and media personnel in situations involving armed conflict. Amended a year later after the Iraq invasion, this reiterated IHL protections for journalists, reaffirmation that attacks on journalists and media representatives are unlawful, and (given what happened to the Belgrade television station in 1999 or to the Al-Jazeera facilities in Kabul in November 2002) ensure appropriate precaution prior to military action. This Declaration further asserted that journalists have a right to identical protection regardless of their professional status. 
In January 2007, the Council of Europe called on all national parliaments to respect freedom of expression and protect journalists from intimidation. It recommended a monitoring system to identify such threats and to monitor national investigation of such attacks (Council of Europe 2007).

Later in 2007, a Colombian conference on press freedom organised by UNESCO issued the Medellin Declaration which called on news organisations to ensure safety of their personnel by training, healthcare, life insurance, and access to social protections for both freelance and fulltime staff. The Declaration further called on UNESCO member states to ensure that respect for freedom of expression and a willingness to combat impunity, constituted conditions for granting financial assistance.

Overall, the implementation of IHL is at best a patchwork quilt. But it does provide an extensive body of rules that are operative and subscribed to. These rules, which some argue require further elaboration for journalist protection, are good friends to this profession. Without a basic understanding of this law and the legal norms it creates, a journalist might easily misreport events. The previously cited William Orme (2007) offers a sound rule of thumb advice to journalists: 'Never pretend to be what you are not, or deny being what you are unless your life depends on it. Carry a camera, but never a gun. And keep that dog-eared copy of the Geneva Conventions in your breast pocket until after the shooting stops'.

\section{Looking ahead}

Given the essential need for, yet limitations of IHL to adequately reduce the risks facing journalists working in combat locations, what other measures might deserve consideration? Given the preponderance of internal conflict events, strategies are needed to strengthen the rule of law at national levels, formidable though the linkage connecting impunity, corruption and poverty remains. The poor salaries and absent professional standards evident among national law and security enforcement agencies in war-torn states persist as cumulative legacies of neglected state infrastructure and general impoverishment.

International news media exposure of these national defects - whether by reporting international 'naming and shaming', or use of the conditionality suggested in the just mentioned Medellin Declaration-would not remedy such deficiencies but could contribute to needed reforms. 
Battered and bruised it may be, but the human rights agenda including the evergreen 1948 Universal Declaration and its Article 19 remains compelling. That Article with its plain, unambiguous language continues to convey universal resonance, namely:

Everyone has the right to freedom of opinion and expression; this right includes freedom to hold opinions without interference and to seek, receive and impart information and ideas through any media and regardless of frontiers.

Finally deserving attention is a degree of professional introspection by the news media as to how it goes about providing conflict coverage. Just how imperative is it to provide already violence saturated audiences with the immediacy of combat as it happens, courtesy of embedded journalists who in their hundreds accompanied the 2003 Iraq invasion? Freelance journalists surrounding themselves with bodyguards, and even returning fire as occurred Tikrit, Northern Iraq, in April 2003, are doing neither themselves nor their colleagues any favours (Balgy-Gallois, 2004, p. 5). In fact, the complexities of conflict render its actual violence but part of a total story, key elements of which are too often ignored by the news media. Conceivably the fuller that is appreciated in the newsrooms of the world, the lesser the risks likely to confront journalists handling these most demanding of assignments.

\section{References}

Amnesty International (1997, March 8). Open letter to Prime Minister Sir Julius Chan concerning the recruitment of foreign military personnel for Bougainville, Retrieved on 10 April 2010, from www.amnesty.org/en/library.

Balgy-Gallois, A. (2004). The protection of journalists and news media personnel in armed conflict. International Review of the Red Cross 86,853: 37-76.

Council of Europe (2007). Resolution 1535: Threats to the lives and freedom of expression of journalists. Retrieved on 16 December 2009, from http://assembly. coe.int/main.asp?Link=/documents/adoptedtext/ta07/eres1535.htm

Durham, Helen (2008). The laws of war and traditional cultures: A case study of the Pacific region. Commonwealth Law Bulletin, 24(4): 833-841.

Dworkin, A. G., Roy Rieff, D. (Eds). (2007). Crimes of war: What the public should know. London: Crimes of War Project.

Duffield, M. (2001). Global governance and the new wars: The merging of development and security. London: Zed Books. 
ICRC (International Committee of the Red Cross). (2007). Covering war and disaster. Report on special meeting on media safety and IHL in war reporting, Geneva, 26 November 2007. Retrieved on 16 December 2009, from, www.icrc.oirg/medioaihl-report-261107

ICRC. (2009, August 10). ICRC poll shows rules of armed conflict enjoy broad support but are considered to have limited impact, 10 August 2009. Retrieved on 20 December 2009, from www.icrc.org/web/eng/siteeng0.nsf/htmlall/researchinterview-100809

ICRC (2009). Under the protection of the palm: Wars of dignity in the Pacific. Suva, Fiji: ICRC Regional Delegation.

ICRC (2010). Customary International Humanitarian Law (Vols 1 and 2) at: www. icrc.org

Lisosky, J. M., and Henrichsen, J. (2009). 'Don't shoot the messenge'r: Prospects for protecting journalists in conflict situations. Media, War and Conflict, 2(2): 129-148.

Orme, W. (2007). Protection of journalists, Crimes of War A-Z Guide. Retrieved on 16 December 2009, from www.crimesofwar.org/thebook/journalists-protection.html Powell, C. (2001). Remarks to the National Foreign Policy Conference for Leaders of Nongovernmental Organisations, Washington DC, October 26. Retrieved on 16 December 2009, from www.state.gov/secretary/former/powell/remarks/2001/5762.htm.

Pratt, D. (2005). Getting to know international humanitarian law, address to the International Humanitarian Law and Media Workshop, Ottawa, 18 March 2005. Retrieved on 20 December 2009, from www.redcross.ca/article.asp?id=12529\&tid=001

Powell, C. (2001). Remarks to the national foreign policy conference for leaders of nongovernmental organisations, Washington DC, October 26. Retrieved on 16 December 2009, from www.state.gov/secretary/former/powell/remarks/2001/5762. htm.

Dr Roderic Alley is a senior research fellow in the Centre for Strategic Studies at Victoria University of Wellington. He was formerly associate professor in political science and international relations at the university. He is a vice-president of the New Zealand Institute of International Affairs, and has authored several books and academic articles on New Zealand's foreign relations, the contemporary Pacific, the United Nations, disarmament and conflict analysis. He is also co-convenor of the New Zealand National Consultative Committee on Disarmament, and convenor of the New Zealand International Humanitarian Law Committee. roderic.alley@vuw.ac.nz 